\title{
Роль информационной войны в ливийском конфликте 2011 г.: средства и методы
}

\author{
Мохаммед Альбо Таслих
}

В статье предпринята попытка рассмотреть

информационно-пропагандистские технологии, которые использовались государствами членами НАТО в военной кампании против властей Ливии в 2011 г. на фоне обострившегося внутреннего конфликта в этой североафриканской стране.

События в Ливии, в частности, продемонстрировали, каким образом в подобных современных конфликтах традиционные СМИ и новые медиа могут повлиять на исход военного противоборства.

Принимая во внимание актуальность темы, автор проанализировал и систематизировал ключевые аспекты средств и методов информационной войны, применяемых в определенные этапы данного противостояния, обобщив широкий спектр позиций экспертов по этому вопросу.

Ключевые слова: ливийский конфликт 2011 г., информационная война, противоборствующие стороны. (c) Альбо Таслих Мохаммед Имад Кадим аспирант кафедры новых медиа и теории коммуникации факультета журналистики МГУ имени М.В. Ломоносова, Mhmdmad107@gmail.com

\section{Введение}

В 2010-2012 гг. арабский мир потрясли разворачивающиеся по одному сценарию массовые протесты, перевороты и гражданские войны (так называемая "арабская весна»). В некоторых странах все закончилось акциями протеста, вынудившими власть пойти на определенные уступки. В государствах, занимающих стратегическое геополитическое положение в регионе (или обладающих природными ресурсами) и представляющих в связи с этим интерес для мировых игроков, последствия оказались намного серьезнее. Так, в Ливии в силу многих причин протесты переросли в гражданскую войну, в которую впоследствии вмешались коалиционные силы НАТО и ряд стран Лиги арабских государств (ЛАГ). Вместе с тем можно сказать, что одним из основных участников данного противостояния стала информационная война, методы и средства которой в определенные этапы этого противоборства мы рассмотрим далее.

На сегодняшний день существует большое количество научных публикаций и трудов, рассматривающих различные аспекты ливийского конфликта. Однако корпус работ о роли в нем информационной войны (о теории и практике информационной войны см., напр.: Ш.С. Сулейманова, Е.А. Назарова 
(2017); И.Н. Панарин (2012)) представлен недостаточно.

Одной из первых серьезных работ, посвященных войне в Ливии, стала книга А.Д. Цыганка «Война в Ливии - 2011 и ее последствия для Ближнего Востока и Кавказа» (2012). Автор подробно анализирует причины возникновения конфликта, подготовку, ход и последствия операций НАТО, а также затрагивает способы информационного воздействия, использовавшиеся коалицией в ходе конфликта. А.Д. Цыганок указывает на то, что журналисты, освещавшие ливийские события, прямо или косвенно участвовали в информационной войне на стороне сил Альянса.

Анализу методов психологических операций НАТО против населения и военнослужащих Ливии посвящены статьи В. Платонова (2011) и В. Логвинца (2011). Д.Г. Балуев и Д.И. Каминченко (2012) исследуют методы использования коалиционными силами Интернета, в частности социальных сетей Twitter и YouTube, а также мобильных сетей для ведения разведывательной деятельности. Е.В. Михайлевский (2011) рассматривает западные СМИ как субъекты информационной операции против Ливии. Ю.С. Кинаш (2017), исследуя новые возможности информационных технологий в политических конфликтах, в частности в Ливии, отмечает, что их всегда сопровождает информационная война, ведение которой невозможно без посреднических и передаточных функций СМИ, которые зачастую носят деструктивный характер.

Зарубежный исследователь М.К. Форт (2012) анализирует причины возникновения конфликта, приводит документальную историю событий, процессов и решений, которые привели к войне, прогнозирует ее последствия.

Актуальность темы - информационное сопровождение современных политических и военных кампаний, задача которых заключается в изменении режимов в различных регионах мира в интересах политических элит для получения доступа к богатым национальным природным ресурсам ит.д. (на примере ливийского конфликта 2011 г.).

Цель статьи - проанализировать и систематизировать основные аспекты средств и методов информационной войны в определенные этапы ливийского конфликта 2011 г. Принимая во внимание, с одной стороны, актуальность проблемы, а с другой - ограниченность базы источников по данной теме, автор счел целесообразным представить широкий спектр позиций экспертов по этому вопросу.

Статья представляет синтез обобщенной информации, полученной из анализируемых исследований, а также материалов фактической выборки, сделанных автором. В связи с этим в данной статье применялся аналитический метод контент-анализа приведенных выше исследований, а также традиционных СМИ и новых медиа, которые информационно сопровождали военное противостояние в Ливии.

Материалы статьи могут быть использованы при разработке спецкурсов по изучению методов ведения информационных кампаний во время современных политических и военных конфликтов для студентов и аспирантов факультетов и кафедр журналистики.

\section{К вопросу о причинах конфликта и об основных его участниках}

Кратко характеризуя внутриливийское политическое противостояние, нужно отметить, что ливийское общество организовано по племенному принципу, и внутриполитическая ситуация в стране полностью зависит от 40-50 (по мнению экспертов) наиболее значимых и имеющих вес в стране племен, большинство из которых - арабоязычные (о племенной структуре ливийского общества и ее влиянии на политические процессы в стране подр. см.: Зинин, 2013). Политика М. Каддафи, выходца из маленького и не 
очень авторитетного племени, заключалась в поддержании сложного баланса между племенами. Для этого он заключил союз с двумя самыми крупными и влиятельными племенами Триполитании Варфалла и Мегариха, поставил на все важнейшие государственные посты представителей своего клана и лояльных племен, а также подавил политическое и экономическое влияние племен Киренаики, крупнейшим представителем которых является племя Зувайя. «Ядро ливийской оппозиции во время восстания составили племена и кланы Киренаики, восточной части Ливии, в которой сосредоточены наиболее значительные нефтяные и газовые ресурсы страны. До свержения монархии в 1969 г. Киренаика считалась доменом ливийской королевской семьи (король Идрис, сам выходец из этой области, большую часть времени проводил в Бенгази). <...> именно выступление шейха племени Фараджа аз-Зувая, пригрозившего перекрыть экспортные пути поставки нефти, стало сигналом к народному восстанию»1.

1 сентября 1969 г. Муаммар Каддафи возглавил военный переворот против правления короля Идриса I и стал лидером Ливии. И хотя с 1972 г. он официально не занимал никакого поста в правительстве Ливии, Каддафи фактически являлся непререкаемым руководителем правящей верхушки страны, и все его директивы имели силу закона. В своей политической деятельности Каддафи опирался прежде всего на свою семью и партию Арабский социалистический союз. Клан Каддафи и несколько лояльных правительству семей контролировали все основные сферы государства: армию, силы безопасности, средства массовой коммуникации и т.п. В результате сорокалетнего правления Каддафи экономика Ливии к 2010 г. стала одной из самых развитых в регионе. Однако это не исключало экономических и социальных проблем: высокий уровень безработицы, особенно среди молодежи (на 2009 г. - 20,7\%), высочайший уровень коррупции (2,2 балла в индексе восприятия коррупции, по данным Transparency International)2 , крайне низкий уровень политических прав и свобод граждан Ливии. Кроме того, данную ситуацию усугубляли политический застой и идеологический кризис в стране.

Тем не менее, по мнению научного сотрудника Института востоковедения РАН А.Б. Подцероба (2011), «особенностью ливийской смуты является то, что антиправительственные выступления в этой стране не были порождены социально-экономическими причинами <...> Доход на душу населения в Ливии (14,2 тыс. долл. в 2010 г.) был самым высоким в Северной Африке, и его значительная часть распределялась в интересах всего населения <...> пособие по безработице составляло 750 долл. в месяц". Востоковед А.В. Коротаев (2017) считает, что основной причиной гражданской войны стала многолетняя борьба за власть и распределение доходов от добычи нефти между племенами Триполитании и Киренаики. А.Б. Подцероб (2011) и А.В. Коротаев (2017) вместе с тем обращают внимание на то, что серьезнейшим политическим просчетом Каддафи стало отступление от своего главного принципа сохранения межплеменного баланса и провозглашение своего сына Сейф аль-Ислама политическим наследником.

Помимо серьезных внутренних разногласий имелись и внешние. Ливия, как страна - импортер нефти, являлась серьезным игроком на региональном уровне и противостояла Катару и Объединенным Арабским Эмиратам. Именно поэтому Каддафи ликвидировал военные базы НАТО на территории страны и вел антизападную политику. Некоторые крупные экономические проекты - например, «Великая рукотворная река», разработка нефтяных месторождений, введение «золотого динара» - представляли угрозу интересам США, Франции и Великобритании. 
На наш взгляд, причиной начала гражданской войны стала политическая борьба между племенами внутри ливийского общества, а когда оппозицию не поддержала большая часть племен и армия, в конфликт вмешались внешние силы - коалиционные сила НАТО, а также некоторые страны ЛАГ.

\section{Информационная война в Ливии}

Информационное противостояние - неотьемлемая часть любого политического конфликта. В отношении Ливии можно говорить о ведении полноценной информационной войны против правительства страны со стороны оппозиционных сил и стран-агрессоров. Не представляется необходимым в данной статье подробно описывать развитие гражданской войны в Ливии, так как существует множество публикаций, посвященных этому военному противостоянию (см., напр.: Цыганок, 2012; Подцероб, 2011; Forte, 2012). Однако для анализа применявшихся средств и методов информационного воздействия целесообразно выделить три основных этапа (об этапах информационной кампании против ливийского правительства во время военного противостояния см. подр.: Цыганок, 2012).

Первый этап (15 февраля - 19 марта 2011 г.) - начало антиправительственных выступлений, переросших в вооруженный мятеж (до военной операции НАТО). В это время идет усиленная информационная подготовка к очередному (ливийскому) этапу «Арабской весны». Основными задачами информационного воздействия были следующие: 1) довести до максимального напряжения протестные настроения; 2) сформировать в глазах мировой общественности отрицательный образ М. Каддафи и членов его семьи; 3) создать образ бедного угнетенного народа Ливии, безуспешно борющегося с деспотичным режимом; 4) сообщить мировой общественности о том, что режим Каддафи имеет химическое оружие и ливийский лидер готов его применить; 5) дискредитировать внутреннюю и внешнюю политику военно-политического руководства Ливии; 6) ослабить моральнопсихологическое состояние населения и личного состава вооруженных сил Ливии; 7) нейтрализовать пропаганду ливийских государственных СМИ, направленную на формирование политического сознания граждан Ливии (Михайлевский, 2011).

Исследователи отмечают, что одним из основных приемов информационной войны на данном этапе противостояния была дезинформация (в частности, преувеличение количества жертв из-за действий правительственных сил). Сразу после начала акций протеста в Ливии 15 февраля западные издания начали публиковать материалы о жестокости правительства по отношению к митингующим (так, газета La Stampa пишет о заваленных трупами улицах Триполи). По сообщениям организация Human Rights Watch, на 18 февраля в столкновениях погибло 24 человека, 19 февраля - 84, а к 24 февраля сообщается о 2000 убитых. В то же время на арабском канале Al Jazeera говорят о 200 убитых 19 февраля и 300 погибших 21 февраля. Со ссылкой на неизвестных очевидцев, в основном врачей, сообщалось о применении для подавления восстания снайперов, военной техники, а главное - химического оружияз 3 .

В этот период в западных средствах массовой информации опубликованы фото- и видеоматериалы из Ливии «в соотношении 20:1 в пользу повстанцев». Анализ размещенных сюжетов показал, что многие из них не соответствовали действительности. Так, на фоне многочисленных сообщений о боях крайне «мало фото- и видеоматериалов раненых, практически не было показано убитых" вследствие военного конфликта. Специалисты, изучившие видеоматериалы из Ливии, отмечали, «что у повстанцев отсутствовало командование. За три недели гражданской войны в СМИ 
не было продемонстрировано ни одной записи реального боя с повстанцами. Свидетельства об участии тяжелой техники в боях в Ливии практически отсутствуют - в основном это касается города Завийя (там западные фотографы обнаружили один поврежденный танк и отсняли его со всех сторон). На основании этого можно сделать вывод, что организованных отрядов, борющихся против Каддафи и способных уничтожать тяжелую военную технику, силы авиации, не существовало. В руках боевиков, судя по фотографиям, находилось вооружение стран Североатлантического альянса» (Михайлевский, 2011).

Кроме дезинформации на данном этапе широко использовался такой прием психологического воздействия, как манипулирование сознанием. В ведущих мировых изданиях появились публикации о преступлениях, совершаемых Каддафи, членами его семьи и правительством Ливии. Например, итальянское издание La Repubblica пишет о многомиллионном состоянии семьи Каддафи, нажитом, несомненно, «нечестным путем», ей вторит The New York Times, ссылаясь на сайт WikiLeaks, на котором была опубликована информация о том, что «семья полковника присвоила свыше 200 млн долларов из государственных контрактов» 4 . 15 февраля 2011 г. телеканал Al Jazeera coобщил о том, что 213 человек, в основном представители интеллигенции, призвали Каддафи отказаться от власти 5 .

Немецкая Die Welt и испанская El Pais, в свою очередь, пишут об экономических рисках, связанных с событиями в Ливии: «Главную угрозу для европейских экономик представляет инфляция, которую может вызвать рост цен на нефть, если ситуация не стабилизируется в ближайшее время»б. Кроме того, западные СМИ давали понять, что с политикой Каддафи не согласны и арабские государства. В статье «Ливийский кризис вступает в фазу интернационализации» в панарабской газете Al Quds Al Arabi сообщается, что Катар и Объединенные Арабские Эмираты готовы участвовать в операции против режима М. Каддафи․ Египетская газета Al Ahram, отмечая, что Ливия является "дежурным председателем» Лиги арабских государств, пишет: после того как «М. Каддафи применил силу против оппозиции, членство этой страны в ЛАГ было приостановлено» (Михайлевский, 2011).

В это же время ливийское правительство вело активное информационное противоборство, используя все доступные средства. Во-первых, проводилась жесткая аккредитационная политика по отношению к иностранным журналистам. Во-вторых, было заблокировано несколько арабских ресурсов, направленных против правительства Ливии, а в Интернете была прекращена работа некоторых сайтов американских сетей. В-третьих, транслировались регулярные выступления по государственному телевидению и радио сыновей Каддафи и самого лидера Джамахирии (например, уже 19 февраля Сейф Аль Ислам выступил с 45-минутной речью на государственном канале ${ }^{8}$ ) с опровержениями провокационных сообщений.

Говоря об информационном противостоянии во время ливийского конфликта, специалисты отмечают важную роль новых медиа. В первые дни ливийского восстания Twitter-каналы, сайты на YouTube, страницы в Facebook и интернет-блоги, которые принадлежали оппозиционным группам внутри страны или эмигрантам из Ливии, стали одними из основных источников информации и видеорядов о том, что происходит в стране. Новости о переходе Бенгази в руки боевиков и о восстаниях в других городах впервые появились в социальных медиа в феврале 2011 г. Отмечается, что использование мобильных телефонов сыграло также ключевую роль в передаче информации из-за высокого уровня распространения сотовых телефонов среди ливийского населения (со степенью проникновения 
в 134\%). В связи с тем что иностранные журналисты не имели возможности добраться до линии фронта в начале марта, отделы новостей традиционных СМИ создавали специальные команды журналистов для отслеживания каналов социальных медиа на постоянной основе, и многие важные сообщения были основаны на информации, полученной из социальных медиапотоков (Балуев, Каминченко, 2012: 309).

Можно сказать, что в целом информационная кампания правительства Ливии имела положительные результаты внутри страны, однако на международном уровне информационная война была безнадежно проиграна. Основными причинами стали следующие: единственный канал $\mathrm{Al}$ Jamahiriya, вещавший на Европу, арабский мир и Африку, не мог противостоять таким мировым информационным каналам, как BBC, CNN, ABC, NEWS, Fox News, France 24, Al Jazeera; правительство Ливии и Каддафи не достаточно оценили возможности Интернета и не использовали в полном объеме его ресурсы для информационной борьбы. В этой связи А.Д. Цыганок (2012) обращает внимание на интересный факт: веб-сайт Libyan revolutionary central (называл себя "руководящим ливийской революцией») был создан 14 февраля - за день до начала протестов. Как оказалось, он «зарегистрирован в штате Огайо как некоммерческая организация с идентификационным номером 501с3 - свободным от налогов!».

Результатом мощной информационной кампании Запада в отношении действий правительства Ливии против повстанцев стали резолюции Совета Безопасности ООН от 26 февраля «О введении международных санкций против руководства Ливии» и от 17 марта «Введение бесполетной зоны над Ливией». Это дало возможность силам НАТО вторгнуться на территорию Ливии и начать военную операцию «Объединенный защитник», в которой участвовали вооруженные силы Великобритании, Франции,
Соединенных Штатов Америки, Канады, Бельгии, Италии, Испании, Дании.

Второй этап информационной войны в Ливии (19 марта -31 октября 2011 г.) проведение операции НАТО «Объединенный защитник». В это время предусматривается решение следующих задач: 1) обратить внимание общественности на точное соблюдение во время военных действий положений резолюции $\mathrm{OOH}$; 2) показать единство стран НАТО в борьбе с режимом Каддафи; 3) создать имидж военных НАТО как борцов за счастливое будущее ливийского народа (представить нанесение ударов НАТО исключительно по военным объектам); 4) осуществлять ведение разведывательной деятельности, в том числе и с помощью журналистов; 5) представить вооруженные силы коалиции как превосходящего противника по отношению к правительственным силам Ливии с тем, чтобы дезинформировать международную общественность и силы Кадддафи относительно успехов ливийской оппозиции и действий НАТО; б) добиться ослабления морально-психологического состояния населения и личного состава вооруженных сил Ливии (Логвинец, 2011).

Для этих целей так же, как и на первом этапе противостояния, активно применялась дезинформация в сообщениях об оперативной обстановке в стране, о результатах проведения военных операций. Особенно этим отличался канал Al Jazzeera, специализирующийся на производстве и использовании фото- и видеофальшивок, постановочных сцен. Так, сотрудников правопорядка, расстрелянных боевиками Аль Каиды, выдавали за убитых ливийскими военнослужащими мирных жителей. В результате такой агрессивной информационной кампании в европейских странах «не возникало условия для формирования общественных требований ее прекращения, несмотря на высокую затратность боевых действий» (Логвинец, 2011). 
Вместе с тем необходимо подчеркнуть: проанализировав информационное сопровождение ливийского конфликта ведущими мировыми телекомпаниями, эксперты приходят к выводу, что наиболее взвешенно ливийский конфликт освещала телекомпания ВBC World. В своих репортажах она всегда представляла позиции противоборствующих сторон, а в новостях старалась избегать оценочных суждений, проверяя факты и ссылаясь на источники сообщений. Так, в сюжете, посвященном началу операции Североатлантического альянса, в первых кадрах была представлена реакция официальныхливийских властей, назвавших действия сил НАТО варварскими, а повстанцев - сторонниками Аль-Каиды. Затем были показаны антинатовская демонстрация в Триполи и ликующая оппозиция в Бенгази, праздновавшая начало военной кампании против диктатора. По сравнению с ВВC World канал France 24, безусловно, был более ангажирован политически. «В репортажах встречалось большое количество информационных фреймов и стереотипов ("Каддафи - тиран", "«повстанцы герои", “демократия", “народ-освободитель”, "новая свободная страна")». Кроме того, в материалах французской телекомпании отмечалось, что с принятием резолюции по Ливии защита мирного населения, по сути, превращается в норму международного законодательства, а государства - члены ООН приобретают «обязательство действовать» (Кинаш, 2017).

Действовали они целенаправленно. В начале мая 2011 г., как сообщает кувейтское информагентство Kuna, по инициативе ЛАГ в рамках исполнения резолюции Совета Безопасности ООН было прервано спутниковое вещание государственного телевидения Ливийской Джамахирии (UBC). До этого «с различных спутников исчезли и два других поддерживающих Каддафи телеканала, вещавших из Триполи, - Lybia Al Riadhia и Al Shababiyah»9.
Кроме того, проводилась жесткая аккредитационная политика со стороны Альянса, предусматривающая допуск к работе в зоне конфликта только лояльных коалиционным силам журналистов. Для того чтобы контролировать информацию о ходе военных действий, журналистов часто лишали возможности работать непосредственно на месте событий. Вместо этого им предоставлялись официальные сообщения и полученные от военных видео, которые тщательно отбирались и демонстрировались на брифингах для прессы.

В ходе операции «Объединенный защитник» силы коалиции использовали ряд специальных методов ведения психологической войны, поддерживая военные успехи ливийской оппозиции. Так, по сообщениям британской прессы, в частности газеты Daily Mail, одновременно с началом операции НАTO специалисты по психологическим операциям Великобритании приступили к рассылке текстовых сообщений по электронной почте, а также звонили на мобильные и служебные телефоны высокопоставленных офицеров ливийских вооруженных сил. Содержание сообщений и звонков сводилось не только к рекомендации прекратить поддержку своего «скомпрометированного и обречённого на крах лидера», но и представляло прямые угрозы. Например: «У нас имеются GPS-координаты вашего командного пункта. Эти координаты запрограммированы в ракету Storm Shadow». Кроме того, Альянсом были проведены так называемые кибернетические операции в закрытых ливийских правительственных компьютерных сетях, а также телекоммуникационных системах. По мнению экспертов, это позволяло оказывать эффективное психологическое воздействие как на сотрудников правительственных учреждений, так и на воинские подразделения (Платонов, 2011).

Исследователи отмечают также роль агитационной пропаганды (например, 
листовок) в информационно-психологическом воздействии. Так, авиация коалиции неоднократно распространяла листовки над населенными пунктами и позициями правительственных войск в Ливии, особенно в районе локальных боевых действий близ г. Мисрата. Подчеркивается, что листовки, написанные на арабском языке, представляли собой довольно простые агитационные материалы, призывающие «прекратить атаки против мирных ливийцев». При этом такие призывы сопровождались угрозами: «...или вы будете уничтожены» (Платонов, 2011).

По мнению экспертов (Платонов, 2011; Логвинец, 2011), мощным средством психологической борьбы во время военных действий может стать также и радио. С 20 марта 2011 г. самолеты EC-130J «Коммандо соло» (Commando Solo) из состава 193 авиакрыла специальных операций США вели в воздушном пространстве Ливии ежедневные круглосуточные радиопередачи на частоте 6877 кГц на арабском, английском и французском языках. Например, в послании для сухопутных подразделений ливийской армии говорилось: «Немедленно покиньте свои позиции. Режим Каддафи нарушает резолюцию ООН об окончании военных действий в вашей стране. Если вы немедленно оставите позиции, вам не будет причинен вред. Не пытайтесь глушить наши передачи». Транслируемые с борта «Коммандо соло», а также посредством других радиоканалов и специальных передатчиков радиопрограммы адресовались не только солдатам и офицерам ливийской армии, но и работникам портов, экипажам торговых судов и военных кораблей. Пропагандистские радиопрограммы, которые транслировались силами НАТО на частотах, используемых в вооруженных силах Ливии, с одной стороны, преследовали общеполитические цели, а с другой - конкретные тактические задачи.

Важная часть информационной деятельности на войне - получение разведданных.
Спутниковые телефоны с доступом в 3G-сети использовались повстанцами для доступа в Интернет через мобильные сети Туниса для передачи в Twitter координат целей для атак авиации НАТО. «Геоинформационные возможности мобильных устройств позволяли генерировать точные координаты долготы и широты. Таким образом, мобильная связь превратилась в мощное средство наведения воздушных сил НАТО на наземные объекты правительства Каддафи» (Балуев, Каминченко, 2012: 310).

10 июня в Неаполе состоялась прессконференция, на которой командующий подразделениями воздушных сил Великобритании в НАТО Майк Брекен объявил о создании Альянсом специального аналитического центра Operation Unified Protector (OUP). Основная задача Центра - сопоставлять информацию из традиционных военных источников с сообщениями из социальных сетей. «Мы получаем информацию из открытых источников в Интернете, в Twitter, - сказал Брекен. - Назовите мне любой источник из социальных медиа, и наш центр тут же преобразует эту информацию в разведданные» (Балуев, Каминченко, 2012: 310). 31 октября 2011 г. генерал-лейтенант Чарльз Бушар, возглавлявший операцию «Объединенный защитник» в Ливии, в интервью «Радио Канады» отметил, что для усиления этого подразделения было создано несколько информационных сетей. «Разведданные поступали из многих источников, включая средства массовой информации, которые были на земле и давали нам много информации о намерениях и расположениях сухопутных войск». Впервые НАТО признало, что официальные иностранные журналисты в Ливии были агентами Альянса (Цыганок, 2012).

С завершением военной операции информационная кампания не закончилась. Начался следующий, третий, этап, во время которого происходило создание выгодной внутренней и внешней оппозиции трактовки 
событий. Западные СМИ сообщали о победах повстанческих сил над остатками сторонников Каддафи, о гуманитарной помощи населению Ливии со стороны западных стран и правозащитных организаций, формировании нового правительства, возвращении страны к мирной жизни. При этом вскрывающиеся факты военных преступлений, разрушенная экономика, многочисленные жертвы среди мирного населения трактовались как результаты действий правительства и армии Ливии.

\section{Заключение}

Проанализировав средства и методы информационного воздействия в ливийском конфликте 2011 г., можно отметить что начальный этап (период от первых массовых беспорядков до внешнего военного вмешательства в ливийский конфликт) был связан с проведением предварительной информационной кампании по дискредитации ливийского режима и самого Муаммара Каддафи в мировых СМИ. В результате НАТО и его союзникам (некоторым странам ЛАГ) удалось добиться принятия резолюции Совета Безопасности $\mathrm{OOH}$, позволяющей вмешаться во внутренние дела Ливии.

В ходе операции «Объединенный защитник» (второй этап) силы коалиции использовали ряд специальных методов ведения психологической войны, поддерживая военные успехи ливийской оппозиции (например, рассылка угрожающих текстовых сообщений по электронной почте, а также соответствующие звонки на мобильные и служебные телефоны высокопоставленных офицеров ливийских вооруженных сил). Мощным средством психологической борьбы во время военных действий стало радио. Так, самолеты «Коммандо соло» в воздушном пространстве Ливии вели ежедневные круглосуточные радиопередачи на арабском, английском и французском языках с призывом к сторонникам Каддафи немедленно покинуть свои позиции, так как его режим нарушает резолюцию $\mathrm{OOH}$ об окончании военных действий в этой стране. Кроме того, важнейшей частью информационной деятельности стало получение разведданных. Спутниковые телефоны с доступом в 3G-сети использовались повстанцами для доступа в Интернет через мобильные сети Туниса для передачи в Twitter координат целей для НАТО.

После поражения правительства М. Каддафи информационное воздействие не прекратилось. Оно проявилось, в частности, в интерпретации фактов, в сокрытии военных преступлений и т.д. События в Ливии продемонстрировали, каким образом в подобных современных конфликтах традиционные СМИ и новые медиа могут активно повлиять на исход противостояния. Можно предположить, что информационная война в этой североафриканской стране оказала соразмерное с военными действиями влияние на результат конфликта.

\section{Примечания}

${ }^{1}$ Кузнецов А. «Однако»: После Каддафи // ИА Инфо Ислам. 2012. Март, 27. Режим доступа: HYPERLINK "http://www.info-islam.ru/publ/stati/obzory/odnako_posle_ kaddafi/6-1-0-13912"http://www.info-islam.ru/publ/stati/obzory/odnako_posle_ kaddafi/6-1-0-13912 (дата обращения: 11.06.2019).

2 Индекс восприятия коррупции 2010 // Transparency international. Режим доступа: HYPERLINK "https://www.transparency.org/cpi2010/results"https://www.transparency.org/cрi2010/results (дата обращения: 10.06.2019). 
3 «Сущий ад» в ливийском Бенгази - войска ведут огонь по демонстрантам, до 200 погибших // NEWSru.com. 2011. Февр., 20. Режим доступа: HYPERLINK "https:// www.newsru.com/world/20feb2011/bengazi.html"https://www.newsru.com/ world/20feb201l/bengazi.html (дата обращения: 10.06.2019).

4 Волков М. Война против Ливии. Ложь западной пропаганды // Виртуальный клуб Суть времени. 2011. Ноябрь, 30. Режим доступа: HYPERLINK "https://eot.su/ smi/analitika/informatsionnaya-voina-v-livii-nachalo"https://eot.su/smi/analitika/ informatsionnaya-voina-v-livii-nachalo (дата обращения: 10.06.2019).

5 Там же.

${ }^{6}$ Нефтяная угроза // InoPressa.ru. 2011. Февр., 24. Режим доступа: HYPERLINK "https://www.inopressa.ru/article/24Feb201l/elpais/crisis.html"https://www. inopressa.ru/article/24Feb201l/elpais/crisis.html (дата обращения: 11.06.2019).

7 Ливийский кризис вступает в фазу интернационализации // NEWSru.co.il. 2011. Март, 18. Режим доступа: HYPERLINK "http://newsru.co.il/press/18Mar2011/arab_ al01.htmlhttp://newsru.co.il/press/18Mar2011/arab_al01.html" http://newsru.co.il/ press/18Mar2011/arab_al01.htmlhttp://newsru.co.il/press/18Mar2011/arab_al01. html (дата обращения: 20.10.19).

8 Saif Al Islam Al Qadhafi on Libyan and Intl TV 21/02/2011 after 1 a.m. Tripoli time // Ливийские новости - 2011. 2011. Февр., 21. Режим доступа: HYPERLINK "http:// www.kaddafi.ru/2011.html"http://www.kaddafi.ru/2011.html (дата обращения: 11.06.2019).

9 Спутниковое вещание государственного канала Ливии заблокировано // Trend news agency. 2011. Май, 16. Режим доступа: HYPERLINK "https://www.trend.az/ business/it/1876727.html"https://www.trend.az/business/it/1876727.html (дата обращения: 12.06.2019).

\section{Библиография}

Балуев Д.Г., Каминченко Д.И. Политическая роль новых СМИ в ливийском конфликте // Вестн. Нижегородск. ун-та им. Н.И. Лобачевского. Международные отношения. Политология. Регионоведение. 2012. № 2 (1). С. 307-313.

Зинин Ю.Н. Племенная структура ливийского общества и ее влияние на политические процессы в стране // Вестн. МГИМО-ун-та. 2013. № 2 (29). С. 38-41.

Кинаш Ю.С. Возможности информационных т ехнологий в современных политических конфликтах (на примере конфликта в Ливии 2011 г.) // PolitBook. 2017. № 3. С. 172-183.

Коротаев А.В. Дестабилизация: глобальные, национальные, природные факторы и механизмы / А.В. Коротаев, Л.Е. Гринин, Л.М. Исаев, С.Э. Билюга и др. М.: Учитель, 2017.

Логвинец В. Эпоха информационно-психологических операций: Ливия // Пси-фактор - сайт о современных психотехнологиях. 2011. Режим доступа: https://psyfactor. org/psyops/psyops5.htm (дата обращения: 10.06.2019).

Михайлевский Е.В. СМИ как основной субъект информационной операции против Ливии // Институт Ближнего Востока. 2011. Март, 23. Режим доступа:: HYPERLINK "http:// www.iimes.ru/?p=12349"http://www.iimes.ru/?p=12349 9 (дата обращения: 10.06.2019).

Панарин И.Н. СМИ, пропаганда и информационные войны. М.: Поколение, 2012.

Платонов В. Стратегический обман: хроника психологической войны в Ливии // Пси-фактор - сайт о современных психотехнологиях. 2011. Режим доступа: HYPERLINK 
"https://psyfactor.org/psyops/psyops-libya.htm"https://psyfactor.org/psyops/psyopslibya.htm (дата обращения: 10.06.2019).

Подцероб А.Б. Ливийская трагедия - причины и последствия // Институт Ближнего Востока. 2011. Окт., 4. Режим доступа: HYPERLINK "https://centrasia.org/newsA. php?st=1317702840"https://centrasia.org/newsA.php?st=1317702840 (дата обращения: 10.06.2019).

Сулейманова Ш.С., Назарова Е.А. Информационные войны: история и современность: учеб. пособие. М.: Этносоциум, 2017.

Цыганок А.Д. Война в Ливии - 2011 и ее последствия для Ближнего Востока и Кавказа. М.: АИРО-ХХІ, 2012.

Forte M.C. (2012) Slouching Towards Sirte: NATO's War on Libya and Africa. Montreal: Baraka Books. 